\section{Development and validation of the Sleep Disturbances Scale for School-age Children}

Jesús Antonio Moo-Estrella, ${ }^{1}$ Matilde Valencia-Flores, ${ }^{2}$ Gloria Margarita Arankowsky-Sandoval ${ }^{3}$

\begin{abstract}
BACKGROUND: Sleep disturbances constitute an important health problem. However, a valid and reliable sleep scale designed for Mexican elementary school-age children is not currently available.
\end{abstract}

OBJECTIVE: To design and to validate a self-report scale for sleep disturbances in school- age children.

METHODS: Participants were recruited by convenience sampling from public elementary schools in Yucatán, México. Participants were divided in two groups, the first took part in the initial phase of the scale development and the second, were children to whom the final version of the instrument was applied. The instrument was developed in two phases. The first one included the design and application of the pilot test. During the second phase the factorial structure of the scale was obtained as well as the prevalence of sleep disturbances of the sample. The principal components analysis and Cronbach's alpha analysis were used to determine the internal consistency of the scale. The final version of the scale includes 25 items.

RESULTS: We included 838 children from six elementary schools, from which 524 took part in the validation process of the scale. This group included children between the third and sixth grades of elementary school, $51.1 \%$ were girls, with an average age of the total sample of $10.3 \pm 1.3$ years old. Statistical analysis showed 6 major components explaining total variance $(47.8 \%)$ : 1$)$ difficulty initiating sleep $(\alpha=$ $0.77), 2)$; nightmares $(\alpha=0.76) ; 3)$ nocturnal awakenings ( $\alpha=0.71)$; 4) daytime sleepiness ( $\alpha=0.69)$; 5 ) tiredness and difficulty waking up $(\alpha=0.69)$; and 6) somnambulism $(\alpha=0.69)$.

CONCLUSIONS: Sleep Disturbances Scale for School-age Children is an instrument with appropriate psychometric properties which can be useful for screening sleep disturbances in the Mexican children population.

KEYWORDS: Sleep disturbances, self-report scale, validity, reliability, school-aged children.

\footnotetext{
${ }^{1}$ Doctor en Neurociencias, responsable del Laboratorio de sueño, Facultad de Psicología, Universidad Autónoma de Yucatán, México.

${ }^{2}$ Doctora en Neurociencias, Clínica de Trastornos del Dormir, División de Investigación y Estudios de Posgrado, Facultad de Psicología, Universidad Nacional Autónoma de México y Departamento de Neurología y Psiquiatría, Instituto Nacional de Ciencias Médicas y Nutrición Salvador Zubirán, Ciudad de México.

${ }^{3}$ Responsable del Laboratorio de Neurobiología, Universidad Autónoma de Yucatán, México.
}

Recibido: 26 de mayo 2017

Aceptado: 7 de agosto 2017

Correspondencia

garankowsky@gmail.com

Este artículo debe citarse como:

Moo-Estrella JA, Valencia-Flores MV, ArankowskySandoval GM. Development and validation of the Sleep Disturbances Scale for School-age Children. Acta Pediatr Mex. 2018;39(2):121-133. 


\section{Desarrollo y validación de la Escala de Alteraciones del Sueño para Escolares.}

Jesús Antonio Moo-Estrella, ${ }^{1}$ Matilde Valencia-Flores, ${ }^{2}$ Gloria Margarita Arankowsky-Sandoval ${ }^{3}$

\section{Resumen}

INTRODUCCIÓN: los trastornos del sueño constituyen un importante problema de salud. En la actualidad no se dispone de una escala de sueño con validez y confiabilidad diseñada para niños mexicanos en edad escolar.

OBJETIVO: diseñar y validar una escala de autoinforme para trastornos del sueño en escolares.

MÉTODOS: Ios participantes se reclutaron de seis escuelas primarias públicas en Yucatán, México, mediante muestreo de conveniencia. Se dividieron en dos grupos: el primero de participantes en la fase inicial del desarrollo de la escala y, el segundo: niños a quienes se aplicó la versión final del instrumento. Éste se desarrolló en dos fases: la primera de diseño y aplicación de la prueba piloto. La segunda: obtención de la estructura factorial de la escala y prevalencia de trastornos del sueño en la muestra. El análisis factorial de componentes principales y el de alfa Cronbach se usaron para obtener la estructura factorial y consistencia interna de la escala, respectivamente.

RESULTADOS: participaron 838 niños de 6 escuelas; de éstos 524 tomaron parte en el proceso de validación de la escala. Este grupo incluyó niños de tercero y sexto grados de educación primaria, con edad promedio de $10.3 \pm 1.3$ años, $51.1 \%$ eran niñas. La versión final de la escala incluyó 25 ítems, agrupados en seis factores que explicaron $47.8 \%$ de la varianza: 1 ) dificultad para iniciar el sueño $(\alpha=0.77)$; 2) pesadillas $(\alpha=0.76)$; 3) despertares nocturnos $(\alpha=$ $0.71)$; 4) somnolencia diurna $(\alpha=0.69)$; 5) cansancio y dificultad para despertar $(\alpha=0.69)$; y 6) sonambulismo $(\alpha=0.69)$.

CONCLUSIONES: Ia Escala de Alteraciones del Sueño para Escolares es un instrumento con propiedades psicométricas apropiadas que puede resultar de utilidad para evaluar trastornos del sueño en niños de la población mexicana.

PALABRAS CLAVE: alteraciones del sueño, escala de autoinforme, validez, confiabilidad, niños, escolares.

\begin{abstract}
${ }^{1}$ Doctor en Neurociencias, responsable del Laboratorio de sueño, Facultad de Psicología, Universidad Autónoma de Yucatán, México.

2 Doctora en Neurociencias, Clínica de Trastornos del Dormir, División de Investigación y Estudios de Posgrado, Facultad de Psicología, Universidad Nacional Autónoma de México y Departamento de Neurología y Psiquiatría, Instituto Nacional de Ciencias Médicas y Nutrición Salvador Zubirán, Ciudad de México.

${ }^{3}$ Responsable del Laboratorio de Neurobiología, Universidad Autónoma de Yucatán, México.
\end{abstract}

Correspondence garankowsky@gmail.com

\section{INTRODUCTION}

Sleep disturbances have been linked in a bidirectional way to impaired development, behavioral alterations, cognitive deficit and emotional alterations in children. ${ }^{1}$ The prevalence of sleep disturbances in children fall within a wide range, between 6 to $43 \%$, depending on the parameters used to determine sleep disorders in some studies. ${ }^{2-5}$ However, complaints can be 
higher according to the National Sleep Foundation Poll, since $69 \%$ of parents reported that their children showed some sleep problems in the course of the week previous to the interview. ${ }^{6}$

Common sleep disturbances in children include the difficulty to initiate and maintain sleep, present between the 10 and $40 \%, 7,8$ daytime sleepiness, which has been reported to occur between 10 and $65 \% .{ }^{9,10}$ Parasomnias also represent an important complaint, between 6.2 and $14.4 \%$,the more frequent of them being night terrors, somniloquy, enuresis and bruxism. ${ }^{11-13}$ Respiratory problems during sleep can occur up to $7.5 \%,{ }^{14}$ while sleep movement disorders, such as restless legs syndrome and periodic limb movement, occur between 2 and 23\%. ${ }^{15,16}$ Overall, sleep disorders could affect more than $40 \%$ of children. ${ }^{7,17}$

The consequences of sleep disturbances in children include a decrease in academic performance and behavioral disorders. ${ }^{18-20}$ Likewise, daytime sleepiness increases the risk of suffering accidents. ${ }^{21,22}$ When sleep problems are not identified and treated in time, they have a negative impact on physical and mental performance and, more importantly, they represent a trigger factor for mood disorders. ${ }^{23,24}$

In general, sleep instruments for children mainly measure specific aspects like sleep breathing disorders, sleep habits or daytime sleepiness. Thus, the Pediatric Sleep Questionnaire (PSQ), ${ }^{25}$ is designed primarily for the detection of respiratory problems and the Pediatric Daytime Sleepiness Scale (PDSS) to detect somnolence. ${ }^{26}$ On the other hand, existing questionnaires that measure multiple domains are usually for parents. As an example, the Children's Sleep Habits Questionnaire (CSHQ), ${ }^{27}$ which mainly measures: bedtime resistance, difficulty falling asleep, sleep duration, anxiety, waking up after initiating sleep, parasomnias, respiratory disor- ders and excessive daytime sleepiness, and the Sleep Behavior Questionnaire (SBQ), ${ }^{28}$ which includes factors like parasomnias, enuresis, fatigue, sounds while sleeping (teeth grinding or talking) and insomnia.

Self-report sleep instruments for children are scarce, ${ }^{29}$ yet they have a better correlation to objective measures of sleep, as shown by actigraphic techniques. ${ }^{30,31}$ Examples of questionnaires on which children have to inform about their sleep are the Sleep Self-Report (SSR), ${ }^{32}$ designed to measure similar domains as the CSHQ and the Children's report of sleep patterns. ${ }^{33}$

On the other hand, as far as we know, there are not any available children sleep disturbances questionnaires or scales originally validated in the Mexican Spanish-speaking population. Existing instruments in Spanish are adapted versions of the Pediatric Sleep Questionnaire (PSQ), ${ }^{34,35}$ Sleep Self report (SSR) ${ }^{32}$ and the Children's Sleep Habits Questionnaire (CSHQ-SP). ${ }^{36}$

The high worldwide prevalence of sleep disturbances, their impact on school-age children, ${ }^{28,37-39}$, and the lack of valid scales for the Mexican children, justifies the need to design tools for sleep disturbances detection in this population. Under this framework, our goal was to get factorial validation of a scale for the screening of sleep disturbances in school-age children.

\section{METHODS}

\section{Participants}

Participants were children between the third and sixth grades of elementary school, recruited by convenience sampling. Schools were selected randomly from a list registered in the Secretariat of Public Education (SEP) of Yucatán, México. Participants were divided in two groups. The first group took part in the initial phase of the scale 
development and the second group comprised children to whom the final version of the instrument was applied.

\section{Procedure}

The study was approved by the Bioethics Committee of our research center. Afterward, the school authorities received an invitation to participate in the study. Both parents and children were informed about the purpose of the study and those who accepted, signed their consent and voluntary participation. The participants were also informed about the confidentiality of their responses. Administration of the scale was made by psychology students registered in their final year, who were previously trained by the main researchers. The children answered the instrument in their classrooms and during class schedules (7:00 am to 12:00 pm). Instructions were read aloud, and the answers were reviewed to avoid missing data. A researcher remained in each classroom to solve any questions. No participants had more than $5 \%$ of missing values; therefore, no case was excluded from the analysis. This process was the same for both groups.

\section{Instrument}

Sleep Disturbances Scale for School-age Children (EASE, for spanish acronym).

The methodology used for developing and validating the Sleep Disturbances Scale for School-age Children was based on that proposed by Nunnally, et al. ${ }^{40}$ and Streiner et al. ${ }^{41}$ The instrument was developed in two phases. The first one included the design and application of the pilot test. During the second phase the factorial structure of the scale was obtained as well as the prevalence of sleep disturbances of the sample.

The first version of the instrument consisted of 48 self-administered questions, aimed at iden- tifying sleep disturbances according to those previously reported in the field, (CSHQ $,{ }^{27} \mathrm{PSQ},{ }^{25}$ $\left.\mathrm{SBQ}_{,}{ }^{28} \mathrm{PDSS},{ }^{26} \mathrm{SSR}^{, 32}\right)$. In the answer format the children indicated the number of days that each sleep disturbance occurred during the last week: $0=0$ days, $1=1-2$ days, $2=3-4$ days, $3=5-6$ days, and $4=7$ days. To obtain the prevalence of sleep disturbances the following classification was used: without disturbance $=0$ days, minor disturbance $=1-2$ days, with disturbance $\geq 3$ days a week. The instrument included a section of general data (gender, age, and grade), sleeping habitual place (bed or hammock) and other concerning sleep habits and schedules, where the children reported their typical bedtime and wake time in hours and minutes on both weekdays and weekends.

After statistical analysis of the pilot test, the EASE was re-designed, including 35 items (see below). Taking as reference the International Classification of Sleep Disorders (ICSD-2), nine factors were proposed: 1) insomnia, 2) daytime sleepiness, 3) sleep breathing problems, 4) nightmares, 5) night terrors, 6) somnambulism, 7) narcolepsy, 8) circadian rhythm disturbances and 9) parasomnia not specific.

\section{Statistical analysis}

For both pilot test and the final proposal of the EASE, the following analyses were made, according to classical psychometric methodology. ${ }^{40-42}$ Initially, a discrimination index of each item using the item-scale correlation was obtained. The criteria for approval for each item was a value of $\geq 0.25$.

For the pilot test a factor analysis using principal components with orthogonal rotation (Varimax) was performed with all items of the scale. This analysis was attained to select the questions that would remain in the second version of the scale, for which four criteria were considered: 1) the 
items that were grouped within each factor had a conceptual relationship to each other, 2) a minimum factorial weight for each item $\geq 0.35$, 3) an eigenvalue $>1$ for the factor where the item was grouped and 4) Commonalities $\geq .040$.

In the second phase, a principal components analysis with orthogonal rotation (Varimax) was performed with all items of the scale to determine the factorial structure of the EASE. The suitability and viability of the factorial analysis was established using the Kaiser-Meyer-Olkin (KMO) and Bartlett's test of sphericity. A factor analysis would be appropriate if the KMO test reached values above 0.5 , and the Bartlett's test obtained values lower than 0.05. For the selection of factors that would constitute the final version of the EASE, four criteria were used: 1) eigenvalue greater than 1,2) Commonalities $\geq .040$, 3) factorial weight $\geq 0.35$ and 4) Cronbach's alpha coefficient $\geq 0.65$. Reliability was examined using the internal consistency of the scale, which was analyzed using Cronbach's alpha coefficient for the total scale and for each subscale. All statistical analyses were performed using SPSS statistical software version 19.0 (SPSS Inc., Chicago). A p-value of less than 0.05 (twosided) was considered statistically significant.

\section{RESULTS}

\section{Participants}

We included 838 children between the third and sixth grades of elementary school. The first group took part in the initial phase of the scale development and included 314 children $(30.1 \%$ were from rural areas, $69.9 \%$ from an urban regions), with an average age of $11.4 \pm 2.0$ years, $50.6 \%$ of them were girls. The second group comprised 524 children to whom the final version of the instrument was applied. This group was equally distributed by gender ( $51.1 \%$ female, $\chi^{2}=0.275$, $p=0.60$ ), with a mean age of $10.39 \pm 1.3$ years and range between 8 to 13 years old $(35.7 \%$ were from rural areas, $64.3 \%$ from urban areas). The distribution by grade $(25.9 \%$ third, $22.6 \%$ fourth, $28.8 \%$ fifth and $22.6 \%$ sixth) was not statistically significant $(p=0.14)$. The percentage of children sleeping in a hammock was higher than those sleeping in bed $\left(62 \%\right.$ vs $38 \%$, respectively, $\chi^{2}=$ 28.10, $p=0.001$ ). All children were proficient in reading and writing, without difficulties in hearing and vision.

\section{Pilot test analysis}

All of the original 48 questions of the pilot scale were included for the factorial analysis, since all items approved the discrimination index criterion $(\geq 0.25)$. After the factorial analysis of the 48 items only 29 were grouped in 7 factors, since they reached the 3 criteria established. The factors obtained from this first analysis were: nightmares and night terrors $(\alpha=0.79$ ), difficulty maintaining sleep due to organic symptoms $(\alpha=0.69)$, insomnia environment ( $\alpha=0.72$ ), sleep quality ( $\alpha=0.68)$, late insomnia $(\alpha=0.69)$, daytime sleepiness $(\alpha=0.61)$, insomnia stress $(\alpha=0.67)$. As a result of this analysis, the scale was re-structured due to the fact that 19 items were not grouped in any factor and most of the sleep disturbances were related to insomnia. In order to obtain a better structure according to the ICSD-2 for the second version of the scale, 6 different questions were added. Thus, 35 items were assembled in the following nine factors: 1) insomnia, 2) daytime sleepiness, 3) sleep breathing problems, 4) nightmares, 5) night terrors, 6) sleepwalking, 7) narcolepsy, 8) circadian rhythm disturbances and 9) parasomnia not specific.

\section{Factorial Structure and Reliability of the EASE}

After application of the second version of the scale, all items approved the discrimination index criterion. Kaiser-Meyer-Olkin (KMO = $0.894)$ and Bartlett's tests $(p=0.001)$ results were 
adequate to continue with the factor analysis using principal components with orthogonal rotation. Items commonalities were in the range of 0.48 and 0.74 except for "You felt afraid of falling asleep during daytime", with a value of 0.34 . Factorial Structure generated 9 factors from which 3 had to be eliminated because they did not approve the selection criterion and were not conceptually clear and did not include at least three questions. Removed factors were: narcolepsy, circadian rhythm disturbances and not specific parasomnia. In addition, "sleep breathing problems" and "night terrors" were united in a single factor renamed "nocturnal awakenings." As a result of the factorial analysis 10 questions were eliminated, and the final scale was integrated by 25 questions, with a structure of six factors: 1) difficulty initiating sleep, 2) nightmares, 3) nocturnal awakenings, 4) daytime sleepiness, 5) tiredness and difficulty waking up and 6) somnambulism. Appendix 1 shows the final version of the EASE.

The total percentage of the explained variance for the EASE was $47.8 \%$, being the first factor "difficulty initiating sleep" the one that obtained slightly over half of this percentage $(25.5 \%)$, whereas each one of the five remaining factors contributed between 6.5 and $3.6 \%$ to the total variance. The factor that added the lowest variance was somnambulism. Likewise, the reliability level of the total scale obtained by the Cronbach's alpha method was 0.91. The internal consistency by factors fluctuated between 0.77 and 0.69 . The factor with the highest reliability was "difficulty initiating sleep" and the lowest was "somnambulism" Table 1).

\section{Prevalence of sleep disturbances}

Descriptive data of each factor and corresponding questions are shown in Table 2. In general, factors were comprised within one standard deviation around the theoretical mean $(2$, in a scale from 0-4). On the other hand, general prevalence of sleep disturbances are depicted in Table 3. The sleep disturbance with the highest percentage of complaints was "tiredness and difficulty waking up", present in $68 \%$ of cases, of which one third $(32 \%)$ occurred between one to two days and $36 \%$ during 3 or more days a week. The second disturbance was "daytime sleepiness", present in $61 \%$ of the sample. Furthermore, the disturbance with the lowest percentage of complaints was "nocturnal awakenings", only present in 18\%.

Prevalence of sleep disturbances according to sociodemographic features in those children presenting sleep disturbances during $\geq 3$ days a

Table 1. Factor Analysis and internal consistency (Cronbach's $\alpha)$ of the EASE. (Continúa en la siguiente página)

\begin{tabular}{|c|c|c|c|}
\hline Factors and questions & $\begin{array}{l}\text { Factorial } \\
\text { weight }\end{array}$ & Variance & $\alpha$ \\
\hline \multicolumn{4}{|l|}{ F1. Difficulty initiating sleep } \\
\hline $\begin{array}{l}\text { 31. You lie down but } \\
\text { weren't sleepy }\end{array}$ & .738 & \multirow{5}{*}{25.5} & \multirow{5}{*}{0.77} \\
\hline $\begin{array}{l}\text { 24. You couldn't sleep } \\
\text { despite having the time } \\
\text { to do it }\end{array}$ & .714 & & \\
\hline $\begin{array}{l}\text { 28. You couldn't sleep } \\
\text { despite having the } \\
\text { adequate space to do it }\end{array}$ & .697 & & \\
\hline $\begin{array}{l}20 . \text { You felt worried for not } \\
\text { being able to sleep }\end{array}$ & .505 & & \\
\hline $\begin{array}{l}\text { 33. You couldn't sleep } \\
\text { well and didn't know why }\end{array}$ & .444 & & \\
\hline \multicolumn{4}{|l|}{ F2. Nightmares } \\
\hline 4. You had nightmares & .693 & \multirow{4}{*}{6.5} & \multirow{4}{*}{0.76} \\
\hline $\begin{array}{l}\text { 19. You dreamed some- } \\
\text { thing that made you feel } \\
\text { scared }\end{array}$ & .649 & & \\
\hline 12. You woke up scared & .626 & & \\
\hline $\begin{array}{l}\text { 29. You woke up sweat- } \\
\text { ing for something you } \\
\text { dreamed }\end{array}$ & .562 & & \\
\hline \multicolumn{4}{|l|}{ F3. Nocturnal awakenings } \\
\hline $\begin{array}{l}\text { 11. You woke up because } \\
\text { you choked }\end{array}$ & .698 & & \\
\hline $\begin{array}{l}\text { 14. You woke up and felt } \\
\text { that you couldn't move }\end{array}$ & .595 & & \\
\hline
\end{tabular}


Table 1. Factor Analysis and internal consistency (Cronbach's $\alpha)$ of the EASE. (Continuación)

\begin{tabular}{|c|c|c|c|}
\hline Factors and questions & $\begin{array}{l}\text { Factorial } \\
\text { weight }\end{array}$ & Variance & $\alpha$ \\
\hline $\begin{array}{l}\text { 25. You snored (someone } \\
\text { told you or you knew) }\end{array}$ & .570 & \multirow{3}{*}{4.5} & \multirow{3}{*}{0.71} \\
\hline $\begin{array}{l}\text { 13. You were told that } \\
\text { you woke up scared and } \\
\text { screaming but don't } \\
\text { remember }\end{array}$ & .491 & & \\
\hline $\begin{array}{l}26 . \text { You were told that you } \\
\text { woke up crying but do not } \\
\text { remember }\end{array}$ & .431 & & \\
\hline \multicolumn{4}{|l|}{ F4. Daytime sleepiness } \\
\hline $\begin{array}{l}\text { 2. You really wanted to } \\
\text { sleep during the day }\end{array}$ & .719 & \multirow{4}{*}{4} & \multirow{4}{*}{0.69} \\
\hline $\begin{array}{l}\text { 30. You fell asleep while } \\
\text { watching TV during the day }\end{array}$ & .642 & & \\
\hline $\begin{array}{l}\text { 15. You fell asleep just by } \\
\text { closing your eyes during } \\
\text { the day }\end{array}$ & .601 & & \\
\hline $\begin{array}{l}\text { 9. You fell asleep and } \\
\text { dreamed a several times } \\
\text { during the day }\end{array}$ & .476 & & \\
\hline \multicolumn{4}{|c|}{ F5. Tiredness and difficulty waking up } \\
\hline $\begin{array}{l}\text { 10. You woke up more } \\
\text { tired than when you laid } \\
\text { down }\end{array}$ & .643 & \multirow{4}{*}{3.7} & \multirow{4}{*}{0.69} \\
\hline $\begin{array}{l}\text { 35. It was hard for you to } \\
\text { wake up in the morning }\end{array}$ & .535 & & \\
\hline $\begin{array}{l}\text { 21. You felt the need to lay } \\
\text { down and wake up later } \\
\text { than others }\end{array}$ & .452 & & \\
\hline $\begin{array}{l}\text { 17. You felt tired most of } \\
\text { the day }\end{array}$ & .402 & & \\
\hline \multicolumn{4}{|l|}{ F6. Somnambulism } \\
\hline $\begin{array}{l}\text { 6. You sleepwalked (some- } \\
\text { one told you or you knew) }\end{array}$ & .807 & \multirow{3}{*}{3.6} & \multirow{3}{*}{0.69} \\
\hline $\begin{array}{l}\text { 32. You sat or stood while } \\
\text { sleeping (someone told } \\
\text { you or you knew) }\end{array}$ & .693 & & \\
\hline $\begin{array}{l}\text { 22. You sleep talked } \\
\text { (someone told you or you }\end{array}$ & .613 & & \\
\hline & Total & 47.8 & .91 \\
\hline
\end{tabular}

Note: Table 1 version in English is for informative value, since the development of the original instrument was is Spanish.
Cuadro 1. Análisis factorial y consistencia interna ( $\alpha$ de Cronbach) del EASE. (Continúa en la siguiente página)

\begin{tabular}{|l|c|c|c|}
\hline Factores y preguntas & $\begin{array}{c}\text { Peso } \\
\text { Factorial }\end{array}$ & $\begin{array}{c}\% \\
\text { Var }\end{array}$ & A
\end{tabular}

\section{F1. Dificultades de inicio de sueño}

31. Te acostaste pero no tenías $\quad .738$ sueño

24. No podías dormir a pesar de tener tiempo para hacerlo

28. No podías dormir a pesar de tener el espacio adecuado $25.5 \quad 0.77$ para hacerlo

20. Te sentiste preocupado(a) por no poder dormir

33. No dormiste bien y no sabías por qué

\section{F2. Pesadillas}

\section{Tuviste pesadillas}

19. Soñaste algo que te dio miedo

$\begin{array}{llll}\text { 12. Despertaste con miedo } & .626 & 6.5 & 0.76 \\ \begin{array}{l}\text { 29. Despertaste sudando por } \\ \text { algo que soñaste }\end{array} & .562 & & \end{array}$
algo que soñaste

\section{F3. Despertares nocturnos}

11. Despertaste porque te atragantaste

14. Despertaste y sentiste que $\quad .595$ no podías moverte

25. Roncaste (te lo dijeron o $\quad .570$ lo sabes)

13. Te dijeron que despertaste asustado (a) y gritando pero no te acuerdas

26. Te dijeron que despertaste Ilorando pero no te acuerdas

\section{F4. Somnolencia diurna}

2. Tenías muchas ganas de dormir en el día

30. Te dormiste viendo tele durante el día

15. Con cerrar los ojos te dormías durante el día

9. Te dormiste y soñaste varias veces durante el día

\section{Alfa}

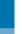


Cuadro 1. Análisis factorial y consistencia interna ( $\alpha$ de Cronbach) del EASE. (Continuación)

\begin{tabular}{|c|c|c|c|}
\hline Factores y preguntas & $\begin{array}{c}\text { Peso } \\
\text { Factorial }\end{array}$ & $\begin{array}{l}\% \\
\text { Var }\end{array}$ & Alfa \\
\hline \multicolumn{4}{|c|}{ F5. Cansancio y dificultades para despertar } \\
\hline $\begin{array}{l}\text { 10. Despertaste más cansado } \\
\text { que cuando te acostaste }\end{array}$ & .643 & & \\
\hline $\begin{array}{l}\text { 35. Fue difícil levantarte en la } \\
\text { mañana }\end{array}$ & .535 & 3.7 & .69 \\
\hline $\begin{array}{l}\text { 21. Sentiste necesidad de } \\
\text { acostarte y levantarte más tarde } \\
\text { que los demás }\end{array}$ & .452 & & \\
\hline $\begin{array}{l}\text { 17. Sentiste cansancio la mayor } \\
\text { parte del día }\end{array}$ & .402 & & \\
\hline \multicolumn{4}{|l|}{ F6. Sonambulismo } \\
\hline $\begin{array}{l}\text { 6. Caminaste dormido/a (te lo } \\
\text { dijeron o lo sabes) }\end{array}$ & .807 & & \\
\hline $\begin{array}{l}\text { 32. Te sentaste o paraste dormi- } \\
\text { do. (te lo dijeron o lo sabes) }\end{array}$ & .693 & 3.6 & .69 \\
\hline \multirow{2}{*}{$\begin{array}{l}\text { 22. Hablaste dormido/a (te lo } \\
\text { dijeron o lo sabes) }\end{array}$} & .613 & & \\
\hline & Total & 47.8 & 0.91 \\
\hline
\end{tabular}

Table 2. Descriptive data of factors and questions of the EASE. (Continúa en la siguiente columna)

\begin{tabular}{|c|c|c|}
\hline Factors & Mean & SD \\
\hline F1. Difficulty iniciating sleep & 2.05 & 0.88 \\
\hline 31. You lie down but weren't sleepy & 2.36 & 1.39 \\
\hline $\begin{array}{l}\text { 24. You couldn't sleep despite having } \\
\text { the time to do it }\end{array}$ & 2.33 & 1.41 \\
\hline $\begin{array}{l}\text { 28. You couldn't sleep despite having } \\
\text { the adequate space to do it }\end{array}$ & 2.28 & 1.34 \\
\hline $\begin{array}{l}\text { 33. You couldn't sleep well and didn't } \\
\text { know why }\end{array}$ & 2.07 & 1.34 \\
\hline $\begin{array}{l}\text { 20. You felt worried for not being able } \\
\text { to sleep }\end{array}$ & 1.74 & 1.18 \\
\hline F2. Nightmares & 1.73 & 0.91 \\
\hline $\begin{array}{l}\text { 19. You dreamed something that made } \\
\text { you feel scared }\end{array}$ & 1.89 & 1.31 \\
\hline 4. You had nightmares & 1.78 & 1.24 \\
\hline $\begin{array}{l}\text { 29. You woke up sweating for something } \\
\text { you dreamed }\end{array}$ & 1.64 & 1.13 \\
\hline 12. You woke up scared & 1.60 & 1.09 \\
\hline F3. Nocturnal awakenings & 1.44 & 0.67 \\
\hline $\begin{array}{l}\text { 14. You woke up and felt that you } \\
\text { couldn't move }\end{array}$ & 1.58 & 1.10 \\
\hline
\end{tabular}

Table 2. Descriptive data of factors and questions of the EASE. (Continuación)

\begin{tabular}{|c|c|c|}
\hline Factors & Mean & SD \\
\hline $\begin{array}{l}\text { 25. You snored (someone told you or } \\
\text { you knew) }\end{array}$ & 1.46 & 1.05 \\
\hline 11. You woke up because you choked & 1.39 & 0.93 \\
\hline $\begin{array}{l}\text { 26. You were told that you woke up cry- } \\
\text { ing but don't remember }\end{array}$ & 1.38 & 0.92 \\
\hline $\begin{array}{l}\text { 13. You were told that you woke up } \\
\text { scared and screaming but don't re- } \\
\text { member }\end{array}$ & 1.34 & 0.87 \\
\hline F4. Daytime sleepiness & 2.25 & 0.92 \\
\hline $\begin{array}{l}\text { 2. You really wanted to sleep during } \\
\text { the day }\end{array}$ & 2.57 & 1.46 \\
\hline $\begin{array}{l}\text { 30. You fell asleep while watching TV } \\
\text { during the day }\end{array}$ & 2.43 & 1.43 \\
\hline $\begin{array}{l}\text { 15. You fell asleep just by closing your } \\
\text { eyes during the day }\end{array}$ & 2.25 & 1.44 \\
\hline $\begin{array}{l}\text { 9. You fell asleep and dreamed a lot of } \\
\text { times during the day }\end{array}$ & 1.99 & 1.32 \\
\hline F5. Tiredness and difficulty waking up & 2.39 & 0.92 \\
\hline $\begin{array}{l}\text { 35. It was hard for you to wake up in } \\
\text { the morning }\end{array}$ & 3.00 & 1.66 \\
\hline 17. You felt tired most of the day & 2.49 & 1.44 \\
\hline $\begin{array}{l}\text { 10. You woke up more tired than when } \\
\text { you laid down }\end{array}$ & 2.36 & 1.45 \\
\hline $\begin{array}{l}\text { 21. You felt the need to lie down and } \\
\text { wake up later than others }\end{array}$ & 2.10 & 1.41 \\
\hline F6. Somnambulism & 1.52 & 0.83 \\
\hline $\begin{array}{l}\text { 22. You sleep talked (someone told you } \\
\text { or you knew) }\end{array}$ & 1.73 & 1.22 \\
\hline $\begin{array}{l}\text { 32. You sat or stood while } \\
\text { sleeping(someone told you or you } \\
\text { knew) }\end{array}$ & 1.47 & 1.01 \\
\hline $\begin{array}{l}\text { 6. You sleepwalked (someone told you } \\
\text { or you knew) }\end{array}$ & 1.37 & 0.91 \\
\hline
\end{tabular}

Note: Table 2 version in English is for informative value, since the development of the original instrument was is Spanish.

Cuadro 2. Datos descriptivos de los factores y preguntas del EASE (contiúa en la siguiente página)

\begin{tabular}{|l|c|c|}
\hline Factores & M & DE \\
\hline F1. Dificultades de inicio de sueño & $\mathbf{2 . 0 5}$ & $\mathbf{0 . 8 8}$ \\
\hline 31. Te acostaste pero no tenías sueño & 2.36 & 1.39 \\
$\begin{array}{l}\text { 24. No podías dormir a pesar de tener } \\
\text { tiempo para hacerlo }\end{array}$ & 2.33 & 1.41 \\
\end{tabular}


Cuadro 2. Datos descriptivos de los factores y preguntas del EASE (continuación)

\begin{tabular}{|c|c|c|}
\hline Factores & M & DE \\
\hline $\begin{array}{l}\text { 28. No podías dormir a pesar de tener el } \\
\text { espacio adecuado para hacerlo }\end{array}$ & 2.28 & 1.34 \\
\hline 33. No dormiste bien y no sabías por qué & 2.07 & 1.34 \\
\hline $\begin{array}{l}\text { 20. Te sentiste preocupado(a) por no } \\
\text { poder dormir }\end{array}$ & 1.74 & 1.18 \\
\hline F2. Pesadillas & 1.73 & 0.91 \\
\hline 19. Soñaste algo que te dio miedo & 1.89 & 1.31 \\
\hline 4. Tuviste pesadillas & 1.78 & 1.24 \\
\hline $\begin{array}{l}\text { 29. Despertaste sudando por algo que } \\
\text { soñaste }\end{array}$ & 1.64 & 1.13 \\
\hline 12. Despertaste con miedo & 1.60 & 1.09 \\
\hline F3. Despertares nocturnos & 1.44 & 0.67 \\
\hline $\begin{array}{l}\text { 14. Despertaste y sentiste que no podías } \\
\text { moverte }\end{array}$ & 1.58 & 1.10 \\
\hline 25. Roncaste (te lo dijeron o lo sabes) & 1.46 & 1.05 \\
\hline 11. Despertaste porque te atragantaste & 1.39 & 0.93 \\
\hline $\begin{array}{l}\text { 26. Te dijeron que despertaste Ilorando } \\
\text { pero no te acuerdas }\end{array}$ & 1.38 & 0.92 \\
\hline $\begin{array}{l}\text { 13. Te dijeron que despertaste asustado } \\
\text { (a) y gritando pero no te acuerdas }\end{array}$ & 1.34 & 0.87 \\
\hline F4. Somnolencia Diurna & 2.25 & 0.92 \\
\hline 2. Tenías muchas ganas de dormir en el día & 2.57 & 1.46 \\
\hline 30. Te dormiste viendo tele durante el día & 2.43 & 1.43 \\
\hline $\begin{array}{l}\text { 15. Con cerrar los ojos te dormías durante } \\
\text { el día }\end{array}$ & 2.25 & 1.44 \\
\hline $\begin{array}{l}\text { 9. Te dormiste y soñaste varias veces } \\
\text { durante el día }\end{array}$ & 1.99 & 1.32 \\
\hline $\begin{array}{l}\text { F5. Cansancio y dificultad para } \\
\text { despertar }\end{array}$ & 2.39 & 0.92 \\
\hline 35. Fue difícil levantarte en la mañana & 3.00 & 1.66 \\
\hline $\begin{array}{l}\text { 17. Sentiste cansancio la mayor parte } \\
\text { del día }\end{array}$ & 2.49 & 1.44 \\
\hline $\begin{array}{l}\text { 10. Despertaste más cansado que cuan- } \\
\text { do te acostaste }\end{array}$ & 2.36 & 1.45 \\
\hline $\begin{array}{l}\text { 21. Sentiste necesidad de acostarte y } \\
\text { levantarte más tarde que los demás }\end{array}$ & 2.10 & 1.41 \\
\hline F6. Sonambulismo & 1.52 & 0.83 \\
\hline $\begin{array}{l}\text { 22. Hablaste dormido/a (te lo dijeron o } \\
\text { lo sabes) }\end{array}$ & 1.73 & 1.22 \\
\hline $\begin{array}{l}\text { 32. Te sentaste o paraste dormido. (te lo } \\
\text { dijeron o lo sabes) }\end{array}$ & 1.47 & 1.01 \\
\hline $\begin{array}{l}\text { 6. Caminaste dormido/a (te lo dijeron o } \\
\text { lo sabes) }\end{array}$ & 1.37 & 0.91 \\
\hline
\end{tabular}

Table 3. Prevalence of sleep disturbances in children.

\begin{tabular}{|l|c|c|c|}
\hline Factors & $\mathbf{1}$ to $\mathbf{2}$ days & $\geq \mathbf{3}$ days & Total \\
\hline & $\%$ & $\%$ & $\%$ \\
\hline $\begin{array}{l}\text { Tiredness and difficulty } \\
\text { waking up }\end{array}$ & 32 & 36 & 68 \\
\hline $\begin{array}{l}\text { Daytime sleepiness } \\
\text { Difficulty iniciating }\end{array}$ & 34 & 27 & 61 \\
\hline $\begin{array}{l}\text { sleep } \\
\text { Nightmares }\end{array}$ & 30 & 20 & 50 \\
\hline Somnambulism & 15 & 13 & 33 \\
\hline Nocturnal awakenings & 13 & 9 & 24 \\
\hline
\end{tabular}

week are shown in Table 4. Thus, comparisons by sex revealed that "somnambulism" $\left(\chi^{2}=\right.$ 7.72, $p=0.005)$ and "nightmares" $\left(\chi^{2}=8.62\right.$, $\mathrm{p}=0.003)$ were more prevalent in boys than in girls. Regarding age, there were significant differences in five factors, those who obtained the higher prevalence were the youngest children $(p<0.05)$. Likewise, children living in urban regions presented more sleep disturbances than those from rural areas, in two factors: "difficulty initiating sleep" (25\% vs $12.8 \%, \chi^{2}=10.85, p=$ $0.001)$, and "somnambulism" (11.3\% vs $4.8 \%$, $\left.\chi^{2}=6.20, p=0.013\right)$. There were not significant differences in any factor between those sleeping in a hammock or bed.

\section{DISCUSSION}

The goal of this study was to obtain the factorial validation of a scale for the screening of sleep disturbances in Mexican, Spanish-speaking children. Results indicate that the EASE is a reliable and valid instrument for the detection of sleep disturbances in school-age children. Thus, the final version of the EASE includes six factors with a satisfactory variance percentage that is very similar to the Spanish versions of the SSR $(46 \%)$, the PDSS (44\%) and the SBQ (58.7\%). Likewise, reliability of the scale had an alpha of 0.91, considered as a good measure of internal consistency, ${ }^{41}$ and was above the alpha value 
Table 4. Sleep disturbances prevalence according to sociodemographic characteristics

\begin{tabular}{|c|c|c|c|c|c|c|}
\hline & DIS & $\mathbf{N}$ & NA & DS & TDWU & S \\
\hline$\leq 3$ days at week & $\%$ & $\%$ & $\%$ & $\%$ & $\%$ & $\%$ \\
\hline \multicolumn{7}{|l|}{ Sex: } \\
\hline Girls & 17.5 & $9 * *$ & 4.5 & 25.7 & 33.2 & $5.6^{* *}$ \\
\hline Boys & 24 & 17.6 & 4.7 & 27.8 & 39.2 & 12.5 \\
\hline \multicolumn{7}{|l|}{ Age } \\
\hline 8 to 9 & $28^{*}$ & $19.3^{*}$ & $9.9^{* *}$ & 32.9 & $51.6^{* *}$ & $14.9^{* *}$ \\
\hline 10 to 11 & 17.9 & 11.3 & 2.3 & 23.3 & 30 & 7.4 \\
\hline 12 to 13 & 16.2 & 8.6 & 1.9 & 25.7 & 27.6 & 3.8 \\
\hline \multicolumn{7}{|l|}{ Zone } \\
\hline Urban & $25^{* *}$ & 11.9 & 3.9 & 27.7 & 37.8 & $11.3^{*}$ \\
\hline Rural & 12.8 & 15.5 & 5.9 & 25.1 & 33.2 & 4.8 \\
\hline \multicolumn{7}{|l|}{ Sleeping place } \\
\hline Hammock & 18.2 & 12.6 & 5 & 28.8 & 35.8 & 6.6 \\
\hline Bed & 23.2 & 14.6 & 3.8 & 23.2 & 35.1 & 8.4 \\
\hline
\end{tabular}

$* \mathrm{p} \leq .05, * * \mathrm{p} \leq .01$

DIS = Difficulty initiating sleep, $\mathrm{N}=$ Nightmares, NA = Nocturnal awakenings, DS = Daytime sleepiness, TDWU = Tiredness and difficulty waking up, $\mathrm{S}=$ Somnambulism.

previously reported for the $\mathrm{PSQ},{ }^{35} \mathrm{CSHQ}-\mathrm{SP}^{36}$ $\mathrm{SSR}^{32}$ and PDSS. ${ }^{26}$

On the other hand, from the nine factors proposed for the theorist design of the scale, only six reached the statistical stablished criteria. However, those factors that were included correspond to the sleep disturbances comprised in the main existing questionnaires reported in the literature. For this reason, our scale could be a useful screening instrument for Spanish-speaking children, based on standard international criteria. Furthermore, in the current literature review we did not find self-report sleep instruments originally designed for Mexican children, thus the proposed scale could fulfill the need of instruments for our population.

Prevalence of the sleep disturbances showed that factors "tiredness and difficulty waking up" and "daytime sleepiness" were the children's main complaints, with a high frequency, close to that $(65 \%)$ previously reported in the literature. ${ }^{10.27,43}$ These disturbances are regularly found in children, and could be the result of other sleep problems occurring during the night, like breathing disorders, insomnia or parasomnias, which can alter both the quality and quantity of sleeping time..$^{14,44-46}$ Sleep habits and sleep hygiene have been also related to daytime sleepiness and tiredness..$^{47,48}$ On the other hand, "nocturnal awakenings" was the factor with the lowest percentage of complaints. This factor is composed by a section of questions related to breathing disorders during sleep, and parasomnias (night terrors and sleep paralysis), which had a similar prevalence to that reported in the literature..$^{14,28}$

Differences related to both sex and age were found in our study. Boys presented more parasomnias than girls, and younger children had more disturbances compared to older kids, both situations had been previously reported in other cultures. ${ }^{9,49}$ Our findings also showed differences 
between children from urban and rural areas. In particular, children living in Merida city showed increased levels of factors associated to sleep initiation difficulties and somnambulism. This situation could be related to the global increase in use of media devices such as computers, internet and mobile telephones by children with better socioeconomic status than those living in rural places. ${ }^{50-53}$ Nonetheless, it is important to consider that our sampled children from rural areas still showed a high prevalence of difficulties initiating sleep, situation which needs further studies. We also found differences in somnambulism prevalence between children from both areas, being lower in those living in rural places. A possible explanation could be that, though somnambulism is considered a common parasomnia, it is also increased by stress situations or influenced by sociocultural activities that are more frequently found in urban areas. ${ }^{54-56}$

In summary, the EASE is a self-report scale of sleep disturbances, with acceptable reliability and factorial validity in school-age children from southeast of Mexico. The EASE measures six factors proposed for research and clinical practice: 1) difficulty initiating sleep, 2) nightmares, 3) nocturnal awakenings, 4) somnambulism, 5) tiredness and difficulty waking up and 6) daytime sleepiness. The prevalence of sleep alterations obtained with the EASE was within the range found by other studies from different countries.

\section{Acknowledgment}

We acknowledge Mr. Steven Woodward for reviewing the English style of the text.

\section{REFERENCES}

1. Gregory AM, Sadeh A. Annual Research Review: Sleep problems in childhood psychiatric disorders-a review of the latest science. J Child Psychol Psychiatry. 2016;57(3):296-317.

2. Ipsiroglu OS, Fatemi A, Werner I, Tiefenthaler M, Urschitz MS, Schwarz B. Prevalence of sleep disorders in school children between 11 and 15 years of age. Wien Klin Wochenschr. 2001;113(7-8):235-244.

3. Mindell JA, Meltzer LJ. (2008) Behavioral sleep disorders in children and adolescents. Ann Acad Med Singapore. 2008;37(8):722-728.

4. Owens J. Classification and epidemiology of childhood sleep disorders. Sleep Medicine Clinics 2007;2(3):353-361.

5. Stallman HM, Kohler M. Prevalence of sleepwalking: a systematic review and meta-analysis. PloS One. 2016;11: e0164769.

6. National Sleep Foundation. Sleep in America poll. 2004 Available at: www.sleepfoundation.org/_content//hottopi cs/2004SleepPollFinalReport.pdf. Accessed April 17, 2006.

7. Fricke-Oerkermann L, Pluck J, SchredI M, Heinz K, Mitschke A, Wiater A, \& Lehmkuhl G. Prevalence and course of sleep problems in childhood. Sleep. 2007;30(10):1371.

8. Paavonen EJ, Aronen ET, Moilanen I, Piha J, Räsänen $E$, Tamminen T, Almqvist F. Sleep problems of schoolaged children: a complementary view. Acta Paediatr. 2000;89(2):223-228.

9. Owens JA, Spirito A, McGuinn M. The Children's Sleep Habits Questionnaire (CSHQ): psychometric properties of a survey instrument for school-aged children. Sleep. 2000;23(8):1043-1052.

10. Muluk NB, Bulbul SF, Turğut M, Ağirtaş G. (2015) Sleep problems of adolescents: A detailed survey. Ear nose throat j. 2015;94(6):E4-E11.

11. Canet-Sanz T, Oltra C. Estudio de las parasomnias en la edad prepuberal. Rev Neurol. 2007;45(1):12-17.

12. Agargun MY, Cilli AS, Sener S, Bilici M, Ozer OA, Selvi $Y$, Karacan $\mathrm{E}$. The prevalence of parasomnias in preadolescent school-aged children: a Turkish sample. Sleep. 2004;27(4):701-5.

13. Laberge L, Tremblay RE, Vitaro F, Montplaisir J. Development of parasomnias from childhood to early adolescence. Pediatrics. 2000;106(1):67-74.

14. Lumeng JC, Chervin RD. Epidemiology of pediatric obstructive sleep apnea. Proc Am Thorac Soc. 2008;5(2):242-252.

15. Picchietti MA, Picchietti DL. Restless legs syndrome and periodic limb movement disorder in children and adolescents. Semin Pediatr Neurol. 2008;15(2):91-99.

16. Martinez S, Guilleminault C. Periodic leg movements in prepubertal children with sleep disturbance. Dev Med Child Neurol. 2004;46(11):765-770.

17. Convertini G, Krupitzky S, Tripodi MR, Carusso L. Trastornos del sueño en niños sanos. Arch Argent Pediatr.2003;101(2):99-105.

18. Rangel Almazán AY, Taboada Camacho BP, Echeverría Camacho N, González Cano S, Telléz Camacho VE, Escobar Briones C, Montemayor Flores BG. Caracterización de ritmos biológicos en una población escolar. Memorias del XLVII del Congreso Nacional de la Sociedad Mexicana de Ciencias Fisiológicas. 2004: 133.http://www.smcf.org.mx/ sitio/documentos/memorias2004.pdf 
19. Carter KA, Hathaway NE, Lettieri CF. Common sleep disorders in children. Am Fam Physician. 2014;85(5):368-77.

20. Fallone G, Acebo C, Arnedt JT, Seifer R, Carskadon MA. Effects of acute sleep restriction on behavior, sustained attention, and response inhibition in children. Percept Mot Skills.2001;93(1):213-229.

21. Shin C, Kim J, Lee S, Ahn Y, Joo S. Sleep habits, excessive daytime sleepiness, and school performance in high school students. Psychiatry Clin Neurosci 2003;57(4):451-453.

22. Amschler DH, McKenzie JF. Elementary students' sleep habits and teacher observations of sleep-related problems.J Sch Health. 2005; 75(2):50-56.

23. Ramtekkar U, Ivanenko A. Sleep in Children with Psychiatric Disorders. Semin Pediatr Neurol. 2015;22(2):148-155.

24. Moo Estrella JA., Valencia Flores M, Ulloa Flores RE, Ostrosky Solís F, \& Reyes Lagunes I. Estructura del sueño y funciones ejecutivas en niños con depresión. Salud mental. 2011;34(5):451-457.

25. Chervin RD, Hedger K, Dillon JE, Pituch KJ. Pediatric sleep questionnaire (PSQ): validity and reliability of scales for sleep-disordered breathing, snoring, sleepiness, and behavioral problems. Sleep Med. 2000;1(1):21-32.

26. Drake C, Nickel C, Burduvali E, Roth T, Jefferson C, Badia P. The pediatric daytime sleepiness scale (PDSS): sleep habits and school outcomes in middle-school children. Sleep. 2003;26(4):455-460.

27. Owens JA, Spirito A, McGuinn M, Nobile C. Sleep habits and sleep disturbance in elementary school-aged children. J Dev Behav Pediatr. 2000;21(1):27-36.

28. Stein MA, Mendelsohn J, Obermeyer WH, Amromin J, Benca R. Sleep and behavior problems in school-aged children. Pediatrics. 2001;107(4):e60.

29. Nascimento-Ferreira MV, Collese TS, de Moraes ACF, Rendo-Urteaga T, Moreno LA, Carvalho HB.Validity and reliability of sleep time questionnaires in children and adolescents: A systematic review and meta-analysis. Sleep Med Rev. 2016;30:85-96.

30. Paavonen EJ, FjällbergM, Steenari MR, Aronen ET. Actigraph placement and sleep estimation in children. Sleep. 2002;25(2):235-237.

31. Holley S, Hill CM, Stevenson J. A comparison of actigraphy and parental report of sleep habits in typically developing children aged 6 to 11 years. Behav Sleep Med. 2010;8(1):16-27.

32. Orgilés M, Owens J, Espada JP, Piqueras JA, Carballo JL.Spanish version of the Sleep Self-Report (SSR): Factorial structure and psychometric properties. Child Care Health Dev. 2012;39(2):288-295.

33. Meltzer LJ, Avis KT, Biggs S, Reynolds AC, Crabtree VM, Bevans KB. The Children's Report of Sleep Patterns (CRSP): a self-report measure of sleep for school-aged children. J Clin Sleep Med. 2013;9(3):235-245.

34. Vila MT, Torres AM, Soto BB.Versión española del Pediatric Sleep Questionnaire. Un instrumento útil en la investiga- ción de los trastornos del sueño en la infancia. Análisis de su fiabilidad. An Pediatr. 2007;66(2):121-128.

35. Bertran K, Mesa T, Rosso K, Krakowiak MJ, Pincheira E, Brockmann PE. Diagnostic accuracy of the Spanish version of the Pediatric Sleep Questionnaire for screening of obstructive sleep apnea in habitually snoring children. Sleep Med. 2015;16(5):631-636.

36. Lucas de la Cruz L, Martínez-Vizcaino V, Álvarez-Bueno C, Arias-Palencia N, Sánchez-López M, Notario-Pacheco B. Reliability and validity of the Spanish version of the Children's Sleep Habits Questionnaire (CSHQ-SP) in schoolage children. Child Care Health Dev. 2016;42(5):675-82.

37. Astill RG, Van der Heijden KB, Van IJzendoorn MH, Van Someren EJ. Sleep, cognition, and behavioral problems in school-age children: A century of research meta-analyzed. Psychol Bull. 2012;138(6):1109-38

38. Dewald JF, Meijer AM, Oort FJ, Kerkhof GA, Bögels SM. The influence of sleep quality, sleep duration and sleepiness on school performance in children and adolescents: a meta-analytic review. Sleep Med Rev. 2010;14(3):179-189.

39. Gruber R, Laviolette R, Deluca P, Monson E, Cornish K, Carrier J. Short sleep duration is associated with poor performance on IQ measures in healthy school-age children. Sleep Med. 2010;11(3):289-294.

40. Nunnally JCB, Arellano IHV. Teoría psicométrica. México: McGraw-Hill. 1995.

41. Streiner DL, Norman GR, Cairney J. Health measurement scales: a practical guide to their development and use. Oxford University Press. 2014.

42. Catell, R. The screen test for number of factors. Multivariate Behav Res. 1966;1:245-276.

43. Spruyt K, O'Brien LM, Cluydts R, Verleye GB, Ferri R. Odds, prevalence and predictors of sleep problems in school-age normal children. J Sleep Res. 2005;14(2):163-176.

44. Alexopoulos EI, Theologi V, Malakasioti G, Maragozidis $\mathrm{P}$, Tsilioni I, Chrousos G, Kaditis AG. Obstructive sleep apnea, excessive daytime sleepiness, and morning plasma TNF- $\alpha$ levels in Greek children. Sleep. 2013;36(11):1633.

45. Kukwa W, Migacz E, Ishman S, Wichniak A. Increased severity of sleep-disordered breathing is associated with insomnia and excessive somnolence in primary school children. Sleep Med. 2016;23:1-5.

46. Simola P, Niskakangas $M$, LiukkonenK, Virkkula P, Pitkäranta A, Kirjavainen T, Aronen ET.Sleep problems and daytime tiredness in Finnish preschool-aged children-a community survey. Child Care Health Dev. 2010;36(6):805-811.

47. Gaina A, Sekine M, Hamanishi S, Chen X, Wang H, Yamagami T, Kagamimori S. Daytime sleepiness and associated factors in Japanese school children. J Pediatr. 2007;151(5):518-522.

48. Surani S, Hesselbacher S, Surani S, Sadasiva S, Surani Z, Surani SS, Subramanian S. Sleep Habits of Elementary and Middle School Children in South Texas. Sleep Disord. 2015(2015):1-9. 
49. Ghalebandi M, Salehi M, Rasoulain M, Shooshtari MH, Naserbakht M, Salarifar M. H. Prevalence of parasomnia in school aged children in Tehran. Iran J Psychiat, 2011;6 (2):75.

50. Li S, Jin X, Wu S, Jiang F, Yan C, Shen X. The impact of media use on sleep patterns and sleep disorders among schoolaged children in China. Sleep. 2007;30(3):361.

51. Oka Y, Suzuki S, Inoue Y. Bedtime activities, sleep environment, and sleep/wake patterns of Japanese elementary school children. Behav Sleep Med. 2008;6(4):220-233.

52. Louzada F, Menna-Barreto L. Sleep-wake cycle in rural populations. Biol Rhythm Res. 2004;35(1-2):153-157.
53. Cain N, Gradisar M. Electronic media use and sleep in school-aged children and adolescents: A review. Sleep Med. 2010;11(8):735-742.

54. Owens JA. Introduction: culture and sleep in children. Pediatrics. 2005;115(1):201-203.

55. Thomas JH, Burgers DE. Sleep is an eye-opener: Behavioral causes and consequences of hypersomnolence in children. Paediatr Respir Rev.2016:152642. doi: 10.1016/j. prrv.2016.11.004.

56. Yang QZ, Bu YQ, Dong SY, Fan SS, Wang LX. A comparison of sleeping problems in school-age children between rural and urban communities in China. J Paediatr Child Health. 2009;45(7-8):414-418. 